\title{
SYSTEM OF GEOGRAPHICAL SCIENCES: UKRAINIAN EXPERIENCE IN THE CONTEXT OF MODERN SUBJECT TRANSFORMATION
}

\author{
1*Oleksandr TOPCHIIEV, '2Daria MALCHYKOVA, 'Vitaliy SYCH, ' Ihor PYLYPENKO, 'Viktoriia YAVORSKA
}

\author{
'Odessa I. I. Mechnikov National University, Ukraine \\ ${ }^{2}$ Kherson State University, Ukraine \\ ${ }^{1 *}$ topch-39@ukr.net
}

\begin{abstract}
The subject transformation of Ukrainian geographical science demonstrates the strengthening of the monistic approach, which considers the Earth's envelope as an integral socio-natural geosphere, in which the natural environment and man with his economic and spiritual activity are inextricably linked. Accordingly, one of the main directions of modern methodological developments is the geographical sciences systematization according to their composition and their multilevel ordering on the basis of the unity and integrity of the common object of geographical research - the landscape envelope of the Earth. The article proposes the authors' scheme of the modern system of geographical sciences, in which the structuring of geographical researches directions is carried out according to the following basic principles: a) the system of geographical sciences is developed not in the list of relevant subjects and disciplines, but in the main areas of geographical research; b) the theoretical and methodological core of the geographical sciences system should be the direction of general integrated geographical research; c) directions of geographical researches and corresponding subject areas and disciplines are organized according to the levels of the landscape envelope structural organization and divided into global (geospheric), regional (country studies, regional studies) and local (environmental and socio-natural activities); d) the proposed systematics does not directly take into account the traditional division of geographical sciences and disciplines into basic - auxiliary - servicing.
\end{abstract}

Key words: system of geographical sciences, geographical envelope, landscape envelope, environment, environmental activities, socio-natural activities.

DOI: https://doi.org/10.17721/2413-7154/2020.83.4-11

UDC: $911.5 / .9$

Received: March 31, 2020

Revised: April 27, 2020.

Accepted: April 30, 2020.

\section{СИСТЕМА ГЕОГРАФІЧНИХ НАУК: ВІТЧИЗНЯНИЙ ДОСВІД В УМОВАХ СУЧАСНОї ПРЕДМЕТНОї ТРАНСФОРМАЦІї}

\author{
1*0лександр ТОПЧІЄВ, ²Дар'я МАЛЬЧИКОВА, 'Віталій СИЧ, 'Ігор ПИЛИПЕНКО, 'Вікторія ЯВОРСЬКА
}

\author{
'Одеський національний університет імені І. І. Мечникова, Україна \\ ${ }^{2}$ Херсонський державний університет, Україна \\ ${ }^{1 *}$ topch-39@ukr.net
}

Анотація: Предметна трансформація української географічної науки демонструє посилення моністичного підходу, що розглядає земну оболонку як цілісну соціоприродну геосферу, в якій нерозривно поєднані природне середовище і людина з її господарською та духовною діяльністю. Відповідно, одним з головних напрямів сучасних методологічних розробок $\epsilon$ систематизація географічних наук за їх складом та багаторівневою впорядкованістю на засадах єдності і цілісності загального об'єкту географічних досліджень - ландшафтної оболонки Землі. В статті запропоновано авторську схему сучасної системи географічних наук, в якій структурування напрямів географічних досліджень здійснене за такими основними принципами: а) система географічних наук розроблена не за переліками відповідних предметів і дисциплін, а за головними напрямами географічних досліджень; б) теоретико-методологічним стрижнем системи географічних наук має виступати напрям комплексних загальногеографічних досліджень в) напрями географічних досліджень та відповідні предметні області і дисципліни систематизовані за рівнями структурної організації ландшафтної оболонки і поділені на глобальні (геосферні), регіональні (країнознавчі, регіонознавчі) та локальні (середовищні і соціоприродні види діяльності); г) у пропонованій систематиці безпосередньо не врахований традиційний поділ географічних наук і дисциплін на основні - допоміжні - обслуговуючі.

Ключові слова: система географічних наук, географічна оболонка, ландшафтна оболонка, довкілля, середовищні види діяльності, соціоприродні види діяльності. 
Постановка проблеми. В умовах становлення державності та прискореного входження української географії у світову науку відбувається iï предметна перебудова, зумовлена подоланням методологічних ідеологем радянських часів та сучасними потребами i запитами суспільства. Головними складовими такої трансформації виступають парадигма сталого (збалансованого) розвитку, екологічний імператив соціально-економічного зростання суспільства, раціональне і виважене природокористування, надійний захист природного середовища, екологічнобезпечна та економічно ефективна територіальна організація населення 3 його господарською діяльністю, планування території. Стрижнем предметної трансформації виступає посилення, а певною мірою і формування моністичного підходу в українській географії, що розглядає земну оболонку якцілісну соціоприродну геосферу, в якій нерозривно і суперечливо поєднані природне середовище і людина з її господарською та духовною діяльністю. Такий підхід певною мірою протистоїть традиційному розмежуванню вітчизняної географії на природничу (фізичну) та суспільну (соціально-економічну) гілки, яке ми одержали у спадок від радянських часів і яке помітно вирізняло нас у світовій географічній науці. Тому вкрай необхідними є методологічні розробки на засадах узагальнюючої методології та теорії, котрі відповідатимуть статусу єдиної географії.

Аналіз останніх публікацій та досліджень. Одним з головних напрямів сучасних методологічних розробок вітчизняної географії є систематизаиія географічних наук за їх складом та багаторівневою впорядкованістю. Актуальність цієї проблеми засвідчують не тільки численні наукові публікації та обговорення - в останні десятиліття її розглядають вже і в освітніх концепціях (Shyschenko et. al., 2000; Concept, 2014) і шкільних підручниках (Dovhan \& Stadnyk, 2019). Наявні праці, в яких обгрунтується об`єкт географії - ландшафтна оболонка Землі як інтегральна соціоприродна геосфера та розкриваються методологічні основи дослідження iii компонентів (Topchiiev, 2005; Topchiiev, 2009; Topchiiev et.al., 2018, тощо). Разом 3 тим рівень теоретико-методологічного розроблення сучасної системи географічних наук в українському освітньонауковому просторі, лишається вкрай недостатнім, фрагментарним i дискусійним. Вітчизняна географічна наука ще зберігає успадковану від радянських часів жорстку розмежованість на «дві географії» - фізичну (природничу) та суспільну (соціально-економічну). Слід згадати й ідеологічну аргументацію таких доволі своєрідних поглядів. Тогочасні ідеологічні цензори радянської географії сповідували несумісність законів природи і законів суспільства, трактували цю тезу марксистської філософії догматично і утилітарно і намагались розвести фізичну та економічну географії до різних областей науки - до природничих і суспільних, відповідно, що жодним чином не узгоджувалось із методологією та науковими поглядами світової географічної науки (Sun et al., 2017). I хоча світова географічна спільнота теж стикнулася з проблемами «дисфункціональності» географії в умовах викликів глобалізації (Dicken, 2004), все ж зарубіжна географічна освітянська i наукова спільнота набагато швидше адаптувалася до трансформацій сучасного світу (Garland et al., 2019; Schmid \& Smith, 2020, тощо).

Ще М. М. Баранський свого часу застерігав молоду радянську географію від формування «безлюдної фізичної географії» та «протиприродної економічної географії», маючи на увазі тенденцію ï прискореного розходження (Baranskii, 1980). Вже у наші дні А. Г. Ісаченко доходить висновку, що географія - одна з найдавніших наук ще й досі «не має загального теоретико-методологічного керівництва». Він пояснює такий феномен предметною специфікою географії, що охоплює природничі та суспільні iii складові, між якими протягом десятиліть (радянський i пострадянський часи) існували «вкрай слабкі контакти» (Isachenko, 2004).

Огляд методологічних розробок системи географічних наук радянського періоду (Mereste \& Nymmik, 1984; Mukitanov, 1979; Saushkin, 1980) і систематик, запропонованих авторами у пострадянській період (Porosenkov, 2005; Golubchik et al., 2005; Gukalova \& Malchykova, 2015; Moroz et. al., 1997; Niemets \& Niemets, 2014) засвідчує актуальність таких пошуків і разом з тим їх певну спрощеність і «однобокість», недостатню розробленість загального теоретичного базису географії. Так, більшість авторів виділяють природничо-географічну та суспільногеографічну (соціально-економічну) підсистеми як головні складові системи географічних наук (Alaev, 1983; Golubchik, 2005; Gukalova \& Malchykova, 2015; Isachenko, 2004; Moroz et. al., 1997; Niemets \& Niemets, 2014; Pistun, 1996; Porosenkov, 2005; Tiutiunnyk, 2011 тощо). Окремі науковці додатково встановлюють підсистеми (блоки) загальногеографічних наук (Saushkin, 1980), природно-суспільних дисциплін (Zhekulin, 1989). Згадаємо і спробу відносити фізичну географію до системи природничих наук, а економічну - до суспільних (Semevskii, 1972).

Деталізовано можна проаналізувати такий дуалістичний підхід до системи географічних наук на прикладі розробленої теми «Система географічних наук» у новітньому шкільному підручнику 3 географіï (Dovhan \& Stadnyk, 2019). Система складена двома підсистемами - природничо-географічних і суспільно-географічних наук. Об'єкт дослідження перших - географічна оболонка Землі як глобальний природний комплекс (без населення та господарства), других - населення та господарство, що їх розглядають поза географічною оболонкою. Показані також «наскрізні» географічні науки - картографія, країнознавство та екологія. Методологічні недоліки даної схеми такі. Система географічних наук не має єдиного об'єкту своїх досліджень: природничогеографічні науки вивчають географічну оболонку, суспільно-географічні - населення та господарство.

(c) Олександр Топчієв, Дар’я Мальчикова, Віталій Сич, Олег Пилипенко, Вікторія Яворська 
Відсутній теоретико-методологічний напрям (блок), що розглядає земну оболонку як єдиний i цілісний об'єкт географічних досліджень, у якому поєднані природа, населення та господарство. Підкреслимо, що саме такий напрям інтегрує (повинен інтегрувати) природничо-географічні науки з суспільно-географічними. Взаємодія фізикогеографічних та суспільно-географічних наук на цій схемі має фрагментарний характер і показана лише на їх «стику». Перелік «наскрізних» географічних предметів вкрай обмежений і дискусійний.

Наведений приклад практично повторює найбільш поширені розробки системи географічних наук і повною мірою зберігає їх методологічні вади. Всі вони нагадують птаха, у якого найбільш помітні його «крила» - фізична та суспільна географії. Щодо «тулуба» й «кістяка», то їх практично немає: маємо лише контури загальногеографічного напряму та його теоретико-методологічних засад. Нагальне завдання вітчизняної географії полягає у розробленні такого напряму на засадах єдності та цілісності об'єкту географічних досліджень.

Потребу у формуванні загальногеографічного напряму досліджень поряд 3 традиційними природничо - та суспільно - географічним вітчизняні науковці усвідомили вже у середині минулого століття. Розроблялися методологічні принципи i методи досліджень інтегрованих геокомплексів і геосистем - природно-господарських, природноекономічних, природно-антропогенних, соціоприродних тощо. У системі географічних наук, розробленій В С. Жекуліним, поряд із звичними природничо-географічним та соціально-економічним позначений i природно-господарський блок, орієнтований на вивчення взаємодії суспільства 3 природою (Zhekulin, 1989). Фізико-географ В. М. Котляков постійно наголошував «єдність і нерозірваність» двох головних гілок географічної науки - природничо-географічної та суспільногеографічної (Kotliakov, 2012). Автори аналітичного огляду розвитку методологічних основ сучасної української суспільної географії (Oliinyk \& Shevchuk, 2011) також акцентують, що наявний поділ географічних наук, який склався не стільки за предметами дослідження, скільки 3 історичних причин, стає все більш неприйнятним, а методологічна єдність географії забезпечить ii повернення до великомасштабного мислення, до узагальнюючої теорії, до поєднання окремих наукових галузей в єдине ціле.

Світовий досвід трансформації напрямків фізико-географічних досліджень підтверджує, що в актуалі сьогоднішньої дослідницької практики обов'язковим є аналіз будь-яких фізико-географічних об'єктів і процесів через призму взаємодії «людинасередовище» (Harden, 2012; Fu et al., 2019 тощо). Доречно відзначити, що сучасні дослідження в галузі фізичної географії (Wainwright, 2012) підкреслюють важливість використання соціальних практик у аналізі і моделюванні стану природних ландшафтів 3 метою отримання цілісної картини довкілля як середовища життєдіяльності. Окремі сучасні зарубіжні дослідження (Shoorcheh, 2019) обгрунтовують єдність географії, засновану на принципі «просторовості» і розумінні неподільності простору у всіх його вимірах - природному, соціально-економічному, культурному тощо.

Зауважимо, що сьогодні нагальна потреба у методологічних розробках на засадах єдності i цілісності об'єкту географічних досліджень пояснюється і запитами практики, численними суспільними ініціативами використання географічних теорії, методології і методичного інструментарію. Зміни, що супроводжують географію 3 початку XXI ст., зумовлені двома основними суспільними інноваціями (Sui, 2011), які певною мірою мають суперечливий характер. По-перше, це так званий «Spatial turn» («просторовий поворот»), що свідчить про збільшення використання географічного мислення і географічних методів аналізу даних в інших науках, навіть гуманітарних. По-друге, це проблема «Big Data» (проблема «великих даних») - за рахунок складності об'єктів географічних досліджень та збільшення технологічних можливостей їх всебічного вивчення географія стала відносно відсталоюз точки зору теорії і методології досліджень, технічних засобів та парадигм дослідження, i стала «обмежуючою» географією (Kitchin, 2013). Географічна економетрична революція загострює необхідність адаптуватися до тенденції «Інтернет+» та епохи великих даних, сприяти розвитку нових концептуальних рамок географії і відповідати на виклики сучасності. Базисом для цього може стати інтеграція напрямів географічних досліджень на засадах єдності і цілісності об'єкту географічних досліджень.

Отже, метою дослідження стала розробка систематики географічних наук на засадах моністичного підходу, відповідно до сучасних предметних трансформацій вітчизняної географічної науки.

Виклад основного матеріалу дослідження. Пропонована авторська схема представляє сучасну систему географічних наук (рис. 1), в якій структурування напрямів географічних досліджень здійснене за наступними принципами i постулатами:

- загальний об'єкт географічних досліджень ландшафтна оболонка Землі як цілісна соціоприродна геосфера;

- система географічних наук розроблена не за переліками відповідних предметів і дисциплін, а за головними напрямами географічних досліджень;

- географічні дослідження згруповані за рівнями організації земної оболонки - глобальним, регіональним, локальним, які надалі позначені як рівні географічних досліджень;

- на локальному рівні представлені середовищний та діяльнісний niдходи, за якими географи досліджують навколишнє середовище (довкілля) життєдіяльності людства та головні види його господарської діяльності;

- окремі підрозділи наведеної систематики мають пошуковий і постановочний характер: такими, 


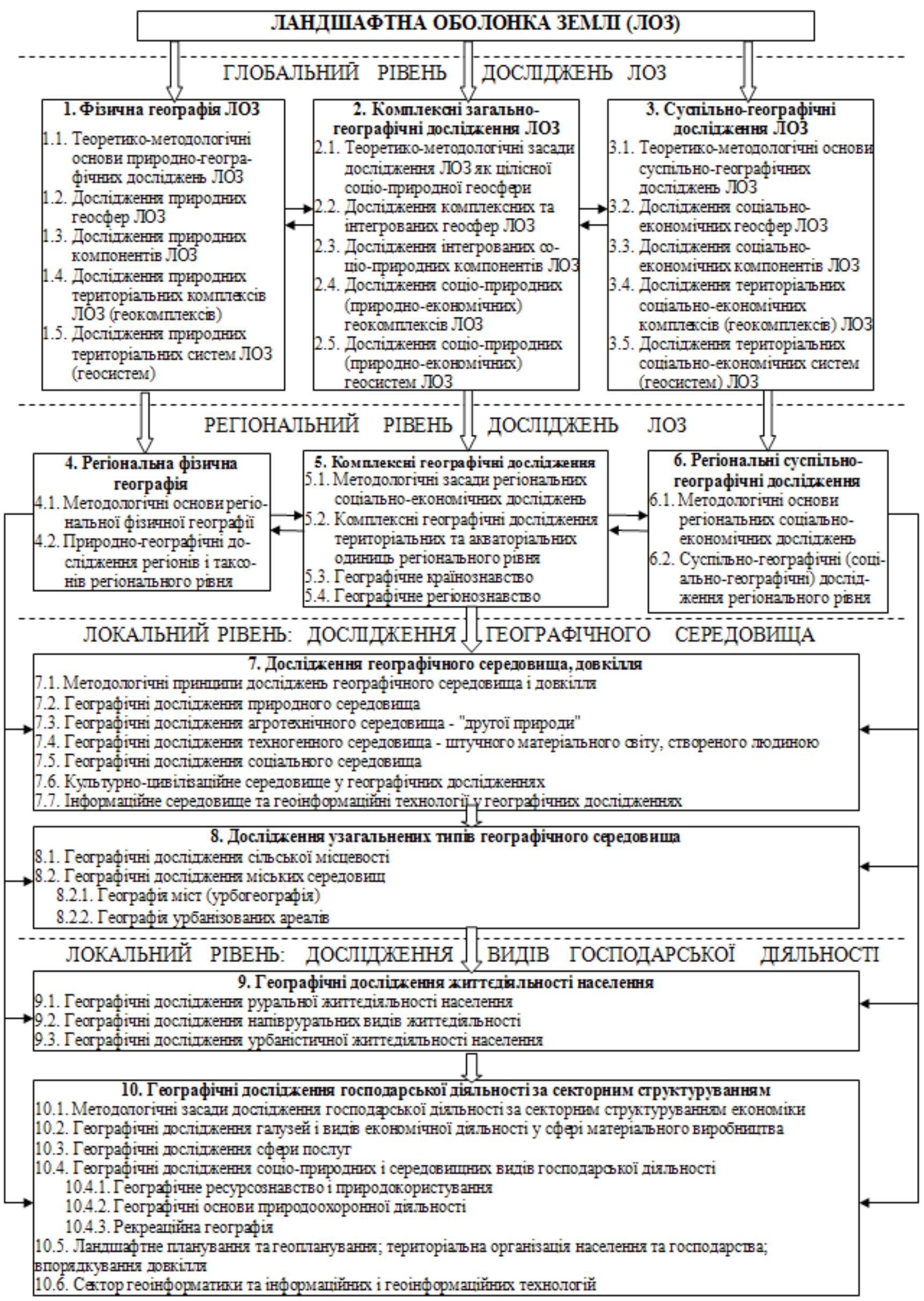

Рис. 1. Система географічних наук за напрямками досліджень. Потовщеними стрілками позначено безпосередні зв'язки, тонкими стрілками - опосередковані (авторська розробка) 
зокрема, є сектори соиіоприродних $i$ середовищнних видів господарської діяльності;

- у пропонованій систематиці безпосередньо не врахований традиційний поділ географічних наук i дисциплін на основні - допоміжні - обслуговуючі.

Єдиним об'єктом досліджень для всієї системи географічних наук є земна оболонка, яку ми розглядаємо як цілісну соціоприродну геосферу, що інтегрує природне середовище, населення з його виробничою та духовною діяльністю і штучний матеріальний світ, створений людиною, і яку ми термінуємо як ландшафтну оболонку Землі. Термін географічна оболонка позначає земну оболонку за ii природними складовими як глобальний природний комплекс, що відповідає його дефініції, i його слід використовувати за таким змістом у природничо-географічних дослідженнях. Відповідне обгрунтування такої термінології вже розглядалося (Topchiiev, 2016; Topchiiev, 2018).

Напрями географічних досліджень та відповідні предметні області і дисципліни систематизовані за рівнями структурної організації ландшафтної оболонки Землі (ЛОЗ) і поділені на глобальні (геосферні), регіональні (країнознавчі, регіонознавчі) та локальні (середовищңно-діяльнісні). Йдеться не лише про масштаби географічних досліджень, але й про їх предметну спрямованість на вивчення геопросторових закономірностей організації земної оболонки на зазначених рівнях. Під середовищними видами діяльності (локальний рівень організації ЛОЗ) розуміємо види господарської діяльності, пов'язані 3 впорядкуванням та територіальною організацією природного середовища, регламентацією взаємин суспільства і природи. Зауважимо, що відповідно до авторського бачення, цю групу надалі необхідно термінувати більш змістовно і функціонально.

На глобальному рівні представлені три напрями географічних досліджень - природногеографічний (фізична географія ЛОЗ), суспільногеографічний (соціально-економічна географія ЛОЗ), загальногеографічний (комплексний), що розглядає земну оболонку як цілісну соціоприродну геосферу. Перші два напрями достатньо відомі і відносно добре розроблені у вітчизняній географії. У їх складі обгрунтування теоретико-методологічних засад природно-географічних та суспільно-географічних досліджень ЛО3, вивчення фізико-географічних та соціально-економічних геосфер і компонентів ЛОЗ, дослідження природних i суспільно-географічних територіальних комплексів (геокомплексів) і територіальних систем (геосистем).

Значно складніша ситуація 3 цілісним розглядом земної оболонки як єдиного об'єкта географічних досліджень, як інтегрованої геосфери. Попри постійні декларації комплексності географічних досліджень, попри намагання дослідників максимальною мірою розглядати всі складові і чинники, що формують земну оболонку - природно-географічні, історикогеографічні, етно-демографічні, соціально-економічні, культурно-історичні, геополітичні та ін., цей напрям у вітчизняній географії теоретичної та методологічно започатковано (Topchiiev et al., 2018), але відповідної методичної розробки і практичного використання у практиці дослідницької і освітянської роботи він і досі не одержав.

Розглянемо складові запропонованої системи (рис. 1). Головним підрозділом загальногеографічного напряму дослідження ЛОЗ $є$ розроблення теоретико-методологічних основ ландшафтної оболонки Землі як єдиного й цілісного об'єкту всієї системи географічних наук і формування відповідного комплексу навчальних дисциплін і предметів. Потребують теоретичної та методологічної розробки концепції соціоприродних та природно-економічних геокомплексів і геосистем.

У вітчизняній географії вже $є$ певний досвід розгляду агроландшафтних, природно-економічних, антропогенно-техногенних, соціоприродних компонентів і геокомплексів, який потребує подальшого методологічного розроблення. У даному огляді соиіоприродними терміновані види діяльності, що поєднують природничі та соціально-економічні ознаки і певною мірою вже наявні у чинних природногеографічних та господарських класифікаціях та рубрикаціях (Sych et al., 2019). Наведемо приклади: природоохоронна діяльність поєднує природногеографічну систематику природних комплексів за їх біосферною цінністю та статистичну класифікацію землекористувань; рекреаційна діяльність пов'язує систематику природного середовища за його оздоровчим потенціалом, з одного боку, і класифікацію видів і форм життєдіяльності населення - 3 другого.

Соцуіоприродні види господарської діяльності у наш час набувають особливої ваги і мають загальну тенденцію до стрімкого зростання. В умовах постіндустріального суспільства і «революції послуг» частка населення, зайнятого у сфері послуг, у розвинених країнах сягає вже 80 - $85 \%$. Разом 3 тим офіційна систематика i класифікація таких видів діяльності вочевидь запізнюється. Згадаймо як приклад туристичну індустрію, яка для багатьох країн i регіонів стала одним 3 головних видів економічної діяльності і яка й досі не позначена окремою рубрикою ні у галузевих класифікаціях, ні у новітніх систематиках видів економічної діяльності.

Географічні дослідження соціоприродних видів господарської діяльності охоплюють природокористування, природоохоронну діяльність, впорядкування природного середовища, геопросторову організацію довкілля та його екологічний захист, планування територій, що об'єднує ландшафтне планування, а також екологічно безпечну та економічно ефективну територіальну організацію населення і господарства. Характерна особливість цієї групи галузей і видів економічної діяльності iii «молодість» і високий динамізм. Державні органи управління природоохоронною та рекреаційною діяльністю створені в Україні відносно недавно. Всі соціоприродні види діяльності швидко зростають i ускладнюються. Стає необхідним структурувати таку групу галузей i видів діяльності як вагомий підрозділ господарства. Вже є пропозиції розглядати соціоприродні види діяльності як сектор чи сферу у складі національних економік, а також як міжгалузеві 
комплекси (кластери) у складі господарства регіонів (Sych et al., 2019).

На другому рівні даної систематики (рис. 1) представлені напрями регіональних географічних досліджень, що включають природно-географічні та суспільно-географічні характеристики територіальних і акваторіальних таксонів регіонального рівня. В обох напрямах наявні теоретико-методологічні складові (блоки), що розробляють принципи і методи відповідних досліджень. Стрижневу роль відіграє третій напрям - комплексних загальногеографічних досліджень регіонального рівня. У його складі розроблення методологічних засад комплексних (соціоприродних) географічних досліджень регіональних територіальних i акваторіальних одиниць, а також географічне країнознавство i регіонознавство. Зауважимо, що у вітчизняній географії саме цей напрям одержав вагому розробку і значний розвиток.

Третій рівень географічних досліджень (рис. 1) об'єднує наукові розробки $і$ предметні області крупних картографічних масштабів, і його названо «локальним». Разом 3 тим такі дослідження географи здійснюють і у більш дрібних масштабах 3 метою їх предметної деталізації та поглиблення відповідних характеристик. Дослідження третього рівня мають і свою предметну специфіку: переважно вони орієнтовані на вивчення географічних середовищ різних типів та характерних видів і форм господарської діяльності, що їм відповідають. Як і на регіональному рівні, такі дослідження представляють загальногеографічний (комплексний) напрям вивчення ЛО3, ii соціоприродних компонентів, геокомплексів і геосистем.

Кониеечія географічного середовищза, розроблена у відомій французькій школі «географії людини» наприкінці XIX ст.,протягом минулого століття певним чином конкурувала 3 екологічним поняттям «навколишнього середовища» і поступилася йому. Останнім часом вона помітно посилена у вітчизняній географії конизепизєю довкілля, що вже має всі ознаки нового наукового напряму (Holubets, 2010; Topchiiev et al., 2017). У географічних дослідженнях наявні два підходи до представлення географічного середовища і довкілля. За першим - традиційним: середовище (довкілля) протистоїть людині (господар середовищної «домівки») і його характеризують i оцінюють для населення, але без самого населення.
За другим: середовище розглядають максимально інтегровано і комплексно 3 усіма його складовими природно-ресурсними, демографічними, соціально-економічними, культурно-історичними та ін. На схемі (рис. 1) представлені головні галузеві різновиди географічного середовища, що потребують відповідного вивчення та оцінки.

Ще одним напрямом локальних географічних досліджень $є$ вивчення різних видів і форм життєдіяльності населення співставно 3 різними типами географічного середовища. Йдеться, зокрема, про розселення населення та його господарську i духовну діяльність. Соціоприродні середовищні географічні дослідження вивчають умови життєдіяльності населення за трьома напрямами: 1) руральні види i форми життєдіяльності; 2) напівруральна господарська діяльність; 3) урбаністичні види і форми життєдіяльності населення. Поширені також і власне середовищні напрями географічних досліджень, за якими вивчають сільську місцевість і міське середовище (у складі якого розрізняють міські поселення та урбанізовані територіi).

Систематика середовищцних напрямів географічних досліджень представлена також їх рубрикацією за секторною (сферною) структурою господарства. Орієнтовний перелік таких секторів та їх предметні області представлені на рис. 1. В умовах постіндустріальної стадії цивілізаційного поступу людства відбувається радикальна перебудова господарства країн і регіонів: відмирають застарілі технології i виробництва, активно формуються нові галузі і види економічної діяльності, які вже слід розглядати як нові сфери господарства, як нові сектори економіки, як нові міжгалузеві комплекси і кластери.

Висновки. Отже, теоретико-методологічним стрижнем системи географічних наук має виступати за авторським баченням напрям комплексних загальногеографічних досліджень, який розпочинається розробленням теоретикометодологічних засад ландшафтної оболонки Землі, методологічним обгрунтуванням інтегрованих геосфер і компонентів ландшафтної оболонки Землі, продовжується географічним країнознавством i регіонознавством i завершується вивченням географічних середовищ різних типів та відповідних видів і форм господарської діяльності населення.

\section{References:}

1. Baranskii, N. N. (1980). Selected Works. Scientific principles of geography. Moscow: Mysl. [In Russian]. [Баранский Н. Н. Избранные труды. Научные принципы географии. М.: Мысль, 1980. 239 с.]

2. Concept of geographic education in primary school (2014). Kyiv: Pedahohichna Dumka. Eds. O. M. Topuzov \& O. F. Nadtoka. [In Ukrainian]. [Концепція географічної освіти в основній школі. Нац. акад. пед. наук України, Ін-т педагогіки; [за заг. ред. авт.: О. М. Топузов, О. Ф. Надтока,.]. К.: Педагогічна думка, 2014.30 с.]

3. Dicken, P. (2004). Geographers and globalization: another missed boat? Transactions, Institute of British Geographers, 29(1), 5-26.

4. Dovhan, G. D., \& Stadnyk, O. H. (2019). Geography. A textbook for 11 class. Kharkiv: Ranok. [In Ukrainian]. [Довгань Г. Д., Стадник О. Г. Географія. Підручник для 11 класу. Харків: Ранок, 2019. 224 с.] 
5. Fu, B., Tian, T., Liu, Y., \& Zhao, W. (2019). New Developments and Perspectives in Physical Geography in China. Chinese Geographical Science, 29, 363-371.

6. Garland, M., Axon, S., Graziano, M., Morrissey, J., \& Heidkamp, C. P. (2019). The blue economy: Identifying geographic concepts and sensitivities. Geography Compass, 13(7). Retrieved from: https://onlinelibrary.wiley.com/ doi/full/10.1111/gec3.12445 [21 April 2020].

7. Golubchik, M. M., Evdokimov, S. P., Maksimov, G. N. et al. (2005). Theory and Methodology of Geographical Science. Moscow: Vlados. [In Russian]. [Голубчик М. М., Евдокимов С, П., Максимов Г. Н. и др. Теория и методология географической науки. М.: Владос, 2005. 463 с.]

8. Gukalova, I. V., \& Malchykova, D. S. (2015). Introduction to the specialty: geography and society. Kherson: OLDI-PLIUS. [In Ukrainian]. [Гукалова I. В., Мальчикова Д. С. Вступ до фаху: географія і суспільство. Навч. посіб. Херсон: ОЛДІ-ПЛЮС, 2015. 268 с.]

9. Holubets, М. А. (2010). Environmental Studies. Lviv: Manuskrypt. [In Ukrainian]. [Голубець М. А. Середовищезнавство (інвайронментологія). Львів: Манускрипт, 2010. 176 с.]

10. Harden, C. P. (2012). Framing and reframing questions of human-environment interactions. Annals of the Association of American Geographers, 102(4), 737-747.

11. Isachenko, A. G. (2004). Theory and Methodology of Geographical Science. Moscow: Akademiya. [In Russian]. [Исаченко А. Г. Теория и методология географической науки. М.: Академия, 2004. 400 с.]

12. Kitchin, R. (2013). Big data and human geography: Opportunities, challenges and risks. Dialogues in Human Geography, 3(3), 262-267.

13. Kotliakov, V. M. (2012). Geography as the most important environmental science. Ekologiya i Zhyzn, 1, 36-42. [In Russian]. [Котляков В. М. География как важнейшая наука об окружающей среде // Экология и жизнь. 2012. № 1. C. 36-42.]

14. Leng, S. et al. (2017). The Geographical Sciences during 1986-2015: From the Classics to the Frontiers. Singapore: The Commercial Press and Springer Science.

15. Mereste, U. I. \& Nymmik, S. Ya. (1984). Modern geography: theory issues. Moscow: Mysl. [In Russian]. [Мересте У. И., Ныммик С. Я. Современная география: вопросы теории. М.: Мысль, 1984. 296 с.]

16. Moroz, S. A., Onopriyenko V. I., \& Bortnyk S. Yu. (1997). Methodology of geographical science. Kyiv: Zapovit. [In Ukrainian]. [Мороз С. А., Онопрієнко В. І., Бортник С. Ю. Методологія географічної науки: навч. посібник. К.: Заповіт, 1997. 333 с.]

17. Mukitanov, N. K. (1979). Methodological theorization of problems in geography. Alma-Ata: Nauka. [In Russian]. [Мукитанов Н. К. Методологические проблемы теоретизации географии. Алма-Ата: Наука, 1979. 187 с.]

18. Niemets, K. A., \& Niemets, L. M. (2014). Theory and methodology of geography: spatial analysis methods. Kharkiv: V. N. Karazin Kharkiv National University. [In Ukrainian]. [Нємець К. А., Нємець Л. М. Теорія і методологія географічної науки: методи просторового аналізу / Навчально-методичний посібник. Х.: ХНУ імені В. Н. Каразіна, 2014. 172 с.]

19. Oliinyk, Ya. B. \& Shevchuk, S. M. (2011). Development of methodological foundations of modern Ukrainian social geography. Ekonomichna ta Sotsialna Geografiya, 63, 3-18. [In Ukrainian]. [Олійник Я. Б., Шевчук С. М. Розвиток методологічних основ сучасної української суспільної географії // Економічна та соціальна географія. Вип. 63. 2011. С. 3-18.]

20. Pistun, M. D. (1996). Theoretical foundations of human geography. Kyiv: Vyscha Shkola. [In Ukrainian]. [Пістун М. Д. Основи теорії суспільної географії. К.: Вища школа, 1996. 230 с.]

21. Porosenkov, Yu. V. (2005). Theory and methodology of geography. Part 1. System of geographical sciences. Voronezh: Voronezh State University. [In Russian]. [Поросенков Ю. В. Теория и методология географии. Часть 1. Система географических наук. Воронеж: Изд-во ВГУ, 2005. 43 с.]

22. Saushkin, Yu. G. (1980). Geographical science in the past, present, future. Moscow: Prosveschenie. [In Russian]. [Саушкин Ю. Г. Географическая наука в прошлом, настоящем, будущем. М.: Просвещение, 1980. 269 c.]

23. Schmid, B., \& Smith, T. (2020). Social transformation and postcapitalist possibility: Emerging dialogues between practice theory and diverse economies. Progress in Human Geography. Retrieved from: https://journals. sagepub.com/doi/10.1177/0309132520905642 [21 April 2020].

24. Semevskii, B. N. (1972). Introduction to Economic Geography. Leningrad: LGU. [In Russian]. [Семевский Б. Н. Введение в экономическую географию: Учеб. пособие. Л.: Изд-во ЛГУ, 1972. 336 с.]

25. Shoorcheh, M. (2018). What Is This Thing Called Geo-graphy? Episodes in the Theorizing of Geo-Human Interactions. International Journal of Environmental Sciences \& Natural Resources, 13(3), 10-12.

26. Shyshenko, P. G., Oliinyk, Ya. B., \& Dmytruk, O. Yu. (2000). Concept of higher geographic educational standard. Kyiv: Tandem. [In Ukrainian]. [Шищенко П. Г., Олійник Я. Б., Дмитрук О. Ю. Концепція стандарту вищої географічної освіти. К.: «Тандем», 2000. 586 с.]

27. Sui, D. (2011). Introduction: Strategic Directions for the Geographical Sciences in the Next Decade. The Professional Geographer, 63(3), 305-309.

28. Sych, V. A., Topchiiev, O. G., Malchykova, D. S., \& Yavorska, V. V. (2019). Socio-natural activities in economic complexes of countries and regions: Problem of conceptualization. In Regional problems of Ukraine: 
geographical analysis and search for solutions. Kherson: Helvetyka, 219-222. [In Ukrainian]. [Сич В. А., Топчієв О. Г., Мальчикова Д. С., Яворська В. В. Соціоприродні види діяльності у господарських комплексах країн і регіонів: концептуалізація питання // Матеріали VIII Всеукраїнської науково-практичної конференції «Регіональні проблеми України: географічний аналіз та пошук шляхів вирішення» (м. Херсон, 3-4 жовтня 2019 р.). Херсон: Видавничий дім «Гельветика», 2019. С. 219-222.]

29. Tiutiunnyk, Yu. G. (2011). Philosophy of Geography. Kyiv: "Ukraina" University. [In Russian]. [Тютюнник Ю. Г. Философия географии. К.: Ун-т «Україна», 2011. 204 с.]

30. Topchiiev, O. G. (2005). Socio-geographical research: methodology, methods, techniques: Textbook. Odesa: Astroprynt. [In Ukrainian]. [Топчієв О. Г. Суспільно-географічні дослідження: методологія, методи, методики: навч. посібник. Одеса: Астропринт, 2005. 632 с.]

31. Topchiiev, O. G. (2009). Fundamentals of social geography: textbook. Odesa: Astroprynt, 2009. [In Ukrainian]. [Топчісв О. Г. Основи суспільної географії: підручник. Одеса: Астропринт, 2009. 544 с.]

32. Topchiiev, O. G. (2016). Subject field of geography and its modern methodological transformation. Ukrainian Geographical Journal, 1, 64-69. [In Ukrainian]. [Топчісв О. Г. Предметна область географії та іiї сучасні методологічні трансформації // Український географічний журнал. 2016. № 1. С. 64-69.]

33. Topchiiev, O. G. (2018). Geographical envelope - landscape envelope: problems of concepts ordination]. In Human geography: scientific traditions and modern challenges (pp. 50-55). Lviv: Ivan Franko Lviv National University. [In Ukrainian]. [Топчієв О. Географічна оболонка - ландшафтна оболонка: проблеми ординації понять / Суспільна географія: наукові традиції та сучасні виклики. Львів: ЛНУ ім. І. Франка, 2018. С. 50-55.]

34. Topchiiev, O. G., Malchykova, D. S., Pylypenko, I. O., \& Yavorska, V. V. (2017). Environmental concept modern integration trend of natural- and socio-geographical research. Ukrainian Geographical Journal, 3(99), 64-70. [In Ukrainian]. [Топчієв О. Г., Мальчикова Д. С., Пилипенко І. О., Яворська В. В. Концепція довкілля - сучасний напрям інтеграції природничо- та суспільно-географічних досліджень // Український географічний журнал. 2017. № 3 (99). C. 64-70.]

35. Topchiiev, O. G., Malchykova, D. S., Pylypenko, I. O., \& Yavorska, V. V. (2018). Methodological foundations of geography: The landscape envelope of the Earth. The environment: Textbook. Kherson: Helvetyka. [In Ukrainian]. [Топчієв О. Г., Мальчикова Д. С., Пилипенко І. О., Яворська В. В. Методологічні основи географії: Ландшафтна оболонка Землі. Довкілля : навч. посіб. Херсон: Видавничий дім «Гельветика», 2018. 348 с.]

36. Wainwright, S. P. (2012). Science studies in physical geography: An idea whose time has come? Progress in Physical Geography, 36(6), 786-812.

37. Zhekulin, V. S. (1989). Introduction to Geography. Leningrad: LGU, 1989. [In Russian]. [Жекулин В. C. Введение в географию. Л.: Изд-во ЛГУ, 1989. 282 с.] 